\title{
27. Cities as democratic representatives in international law-making
}

Samantha Besson and José Luis Marti ${ }^{1}$

\section{INTRODUCTION}

Cities' mayors and authorities, at least those who are democratically elected, are often regarded as representatives of their citizens, whether it is inside or outside the city, ${ }^{2}$ and, in the latter case, both on the national and international plane. ${ }^{3}$ Some of them have actually long played an international role. ${ }^{4}$ However, that role was always limited, and so was its impact on international law. ${ }^{5}$ More importantly, that role, when it existed, was usually conceived as being hierarchically subordinated to that of state authorities, the latter being regarded as the exclusive or, at least, the primary representatives of the sovereign people. ${ }^{6}$ Today, however, cities

1 An early version of this chapter was presented at the conference 'Cities and International Law in the Urban Age' at the Asser Institute, The Hague (13-15 March 2019), at the conference on 'Global Democracy' organized by the University of Buenos Aires (28-29 August 2019) and at the conference 'VI Bilbao European Encounters. Democracy in Europe and Its Critics' organized by the Globernance Institute of Democratic Governance (18-19 November 2019). We would like to thank the organizers of these events and all participants, and in particular Ezequiel Monti for his detailed and excellent feedback. Many thanks also to Sofia Balzaretti, former research assistant at the University of Fribourg, for her editorial assistance.

2 By 'city', we mean a territorially delineated self-governing political community that is, under the current international institutional order, considered either as a subnational institution hierarchically subordinated to the state or as a (city-)state in itself.

3 By 'international' law or institutions, we mean the law or institutions that different peoples qua self-governing political communities adopt together in order to regulate either their external relations or their internal matters. It need not be restricted to inter-state law even if it is the meaning the term jus gentium (literally, the law of peoples) has gradually acquired in modern international law with states being considered as the main representative institutions of those peoples. The relational and hence clearly political dimension of the term 'international' enables one to see more clearly how international law and institutions relate to the people(s) they bind and institute.

4 See, for example, Chapter 35 by Karen Knop in this volume; Janne E. Nijman, 'Renaissance of the City as Global Actors: The Role of Foreign Policy and International Law Practices in the Construction of Cities as Global Actors' in Andreas Fahrmeir, Gunther Hellmann and Miloš Vec (eds), The Transformation of Foreign Policy: Drawing and Managing Boundaries from Antiquity to the Present (Oxford University Press 2016) 209.

5 Cities have long been 'subjects' of rights and duties under international law, but they are now contributing to the making of that international law as 'authorities' thereof. As a result, the question of their (partial) legal sovereignty should not be reduced to that of their legal personality.

${ }_{6}$ This is true as much from the perspective of international law (for example, Christian Dominicé, 'Les collectivités territoriales non-étatiques et la formation du droit international' in Société française pour le droit international (ed.), Les collectivités territoriales non-étatiques dans le système juridique international (Pedone 2002) 55) as from that of domestic law (for example, Chapter 30 by Geneviève Cartier in this volume; Daniel Weinstock, 'Cities and Federalism' in James E. Fleming and Jacob T. Levy (eds), Federalism and Subsidiarity (NYU Press 2014) 259). 
seem to be operating under a very different assumption: many mayors position themselves as privileged and even independent representatives of their citizens on the international scene, especially when their external agendas clash with those of their respective state's government. This is the case in their relations with other cities, but also with international organizations (IOs) and even with foreign states.

The first example one may give is that of the Mayors of New York City and Atlanta who both declared their opposition to President Trump on the United Nations Framework Convention on Climate Change in 2017. Since then, they have pursued their own international environmental agenda by building transnational networks of cities, like the C40 with 96 affiliated cities representing 1 in 12 people worldwide. Many other city networks have arisen in the meantime with their own kind of 'inter-city' law emulating international law, including the Mayors Migration Council or the Healthy Cities Programme. ${ }^{7}$ A second example is that of the city of Rio de Janeiro's negotiation of a loan agreement directly with the World Bank in 2010. Through what may be regarded as an international treaty between an IO and a city, the city committed itself directly, and without Brazil's consent, to launch public-private infrastructure investments. ${ }^{8}$ Finally, one should also mention many cities' participation in international standard-setting procedures. This has been the case, for instance, pertaining to urban governance since 2016 through the Global Network of Safer Cities and in the wake of Sustainable Development Goal (SDG) 11..$^{9}$ The latter has even given rise to a memorandum of understanding (MoU) being adopted, under international law, by the City of New York and a United Nations (UN) Agency, UN Women, in 2016.

In certain recent instances, therefore, it is no longer clear whether states are the only sovereign institutions able to claim general, exclusive and ultimate authority to make international law for their people. It rather seems as if both states and cities (as well as, arguably, other elected public institutions) are exerting their respective, different, partial and not-mutually exclusive sovereignty at the same time. There may actually be good normative reasons to welcome this development in terms of the democratic legitimacy of international law, and we will argue that there are. The conditions for the latter need to be carefully scrutinized, however. Besides the limitations on state sovereignty as we know it or even, in some cases, the total circumvention of states as representatives, indeed, other democratic concerns have grown out of the increasing international involvement of cities. They include concerns about the political representation of non-urban and especially rural populations, but also about the democratic credentials of both cities themselves and the procedures through which they are interacting with other international (public or private) institutions and, last but not least, about the democratic credentials of the latter institutions such as IOs or transnational corporations (TNCs).

\footnotetext{
7 See, for example, Chapter 29 by Sheila R. Foster and Christie Swiney in this volume; Michele Acuto and Steve Rayner, 'City Networks: Breaking Gridlocks or Forging (New) Lock-ins?' (2016) 92(5) International Affairs 1147.

8 See, for example, Chapter 13 by Jacob Katz Cogan in this volume; Michael Riegner, 'International Institutions and the City: Towards a Comparative Law of Local Governance' in Helmut Philipp Aust and Anél du Plessis (eds), The Globalisation of Urban Governance (Routledge 2018) 38.

9 See, for example, Chapter 10 by Yukiko Takashiba in this volume; Chrystie Swiney, 'The Urbanization of International Law and International Relations: The Rising Soft Power and Soft Law of Cities in Global Governance' (2020) 41 (2) Michigan Journal of International Law 227.
} 
There is already a thick body of international law literature describing how cities have emerged as important institutions of international law-making. ${ }^{10}$ Curiously, the normative question of the legitimacy of their participation therein is rarely discussed as such - outside of the not very sophisticated idea that the more 'participation' there is on the part of other 'subjects' to international law than states, the better it must be for the 'inclusion' of all 'stakeholders'. Legitimacy itself is almost never defined in that context. Its political, and especially its democratic, features simply go unaddressed most of the time, not to mention its essential dimension of representation.

Our aim in this chapter therefore is normative, rather than descriptive: based on the existing analyses of the increasing international involvement of cities, we focus on the specific role those cities should play in international law-making as legitimate representatives of their citizens. ${ }^{11}$ The proposed argument follows up on the one we published in 2018 about the legitimate actors of international law-making. ${ }^{12}$ It focuses on cities as one of the multiple and complementary democratic representative institutions currently involved therein. On the basis of a refined version of our theory of international democratic legitimacy (which we summarize in section II), we argue that cities may be regarded as legitimate, and actually privileged, institutions of international law-making qua elected public representatives acting alongside other public (for example, states, IOs) and private (for example, TNCs, non-governmental organizations [NGOs]) institutions (section III). Of course, despite their comparative strengths from a democratic perspective, cities may not claim to exert exclusive international democratic representation - no single type of public institution may do so nowadays - and in fact suffer, we argue, from democratic shortcomings of their own (section IV). Our claim is that we should approach international law-making, at least aspirationally, as a system of multiple international representations in which different public and private institutions, including cities, are combined in order to counterbalance their respective democratic deficits and collectively enhance the representativeness of the system as a whole.

We see this chapter not only as a normative contribution to the international law literature on cities, but also as a warning about the importance of democratic politics in the fast-developing international law-making practice involving cities. ${ }^{13}$ It is a timely reminder to cities that demo-

10 See, for example, Umberto Borsi, 'Municipalisme et internationalisme' in Faculté de droit de Toulouse (ed.), Mélanges Maurice Hauriou (R Sirey 1929) 79; Yishai Blank, 'Localism in the New Global Legal Order' (2006) 47(1) Harvard International Law Journal 263; Helena Lindemann, Kommunale Governance: Das Konzept der Stadt im Völkerrecht (Mohr Siebeck 2014); Helmut Philipp Aust, 'Shining Cities on the Hill? The Global City, Climate Change, and International Law' (2015) 26(1) The European Journal of International Law 255; Janne E. Nijman, 'The Future of the City and the International Law of the Future' in Sam Muller and others (eds), The Law of the Future and the Future of Law (Torkel Opsahl EPublisher 2016) 213; Helmut Philipp Aust, Das Recht der globalen Stadt (Mohr Siebeck 2017); Riegner (n 8).

${ }_{11}$ Because we do not see the analytical question of the 'legality' of international law as entirely distinct from the normative question of its 'legitimacy', we abstain from specifying the concept of 'international law-making' at this stage. As a matter of fact, making sure cities are considered as democratically legitimate representatives may help overcome the process of 'softening' or 'deformalization' of international law they are allegedly contributing to.

12 Samantha Besson and José Luis Martí, 'Legitimate Actors of International Law-Making: Towards a Theory of International Democratic Representation' (2018) 9(3) Jurisprudence 504.

13 See also Simon Curtis, Global Cities and Global Order (Oxford University Press 2016). 
cratic representation comes with not only rights ${ }^{14}$ but also responsibilities. If it is true that cities have the ability to provide more effective answers to many pressing global challenges (for example, economic inequalities, health threats, illegal migration, global warming) due to their proximity to their citizens or their ability to coordinate transnational action, ${ }^{15}$ we also need to make sure they do so more legitimately than they have so far. This does not only mean securing that states (and other institutions) share their role as public representatives of their people(s) with cities ${ }^{16}$ and, conversely, are not circumvented entirely by cities in that role either. ${ }^{17}$ It also requires, moreover, that IOs and TNCs, as well as certain international law regimes in place (such as international economic law ${ }^{18}$ or international sustainable development law ${ }^{19}$ ), do not prevent cities from organizing themselves politically as they should in order to become one of the multiple legitimate public representatives of their citizens in international law-making.

With this warning comes a final caveat. Although our approach relies at least in part on some ideal theorization, we see this chapter primarily as an exercise in non-ideal theory: it reacts to deficits in international democratic representation by making proposals. It is to be expected therefore that some of its proposals suffer from democratic shortcomings of their own.

\section{DEMOCRATIC LEGITIMACY IN INTERNATIONAL LAW-MAKING}

In this chapter, we understand political legitimacy, in quite a standard way, to refer to the questions of who has the right to rule (the right to create legal norms or participate in the creation of such norms) and how such a right to rule should be exerted in order to generate obligations for those subject to such rule. ${ }^{20} \mathrm{We}$ assume moreover that any plausible standard of legitimacy must be democratic. This applies to all laws or institutions, whether national or international. ${ }^{21}$ Of course, abstract democratic principles of legitimacy require different specific institutions in different contexts.

In our view, which again is quite standard, the democratic legitimacy of any law-making institution should be assessed by reference to four basic abstract principles. ${ }^{22}$

\footnotetext{
14 On the so-called 'right to the city', see Chapter 18 by Martha F. Davis in this volume.

15 See Benjamin Barber, If Mayors Ruled the World: Dysfunctional Nations, Rising Cities (Yale University Press 2013).

16 On the exclusion of cities from the negotiations of international trade treaties, see Chapter 22 by Jorge E. Viñuales and Lucy Lu Reimers in this volume.

${ }_{17}$ On the circumvention of states to the benefit of cities by certain IOs, see Chapter 13 by Jacob Katz Cogan in this volume; Riegner (n 8).

18 On the World Bank's agenda for the decentralization of cities in the Global South, see Chapter 22 by Jorge E. Viñuales and Lucy Lu Reimers in this volume.

19 On the SDGs and the standardization of urban politics, see Hannah Birkenkötter, 'Ensuring Access to Public Space as a Dimension of "Safe Cities": The Role of UN Entities in Shaping the Global Urban Governance Agenda' in Aust and du Plessis (n 8) 127.

20 See Besson and Martí, 'Legitimate Actors' (n 12).

${ }_{21}$ See Samantha Besson, 'The Authority of International Law - Lifting the State Veil' (2009) 31(3) Sydney Law Review 343; José Luis Martí, 'Democratic Legitimacy and the Sources of International Law' in Samantha Besson and Jean d'Aspremont (eds), The Oxford Handbook of the Sources of International Law (Oxford University Press 2017) 724.

22 See Martí (n 21).
} 
First of all, the principle of ultimate, effective popular control. It derives directly from the ideal of popular sovereignty: all people(s) affected by international law should have a say in the process of making that law. ${ }^{23}$ They may, of course, delegate that power to representatives. They should, however, retain ultimate, effective control over those representatives and, through them or by other mechanisms, over international institutions and decision-making processes, in order to make popular sovereignty possible. This may take place through periodic elections, but not only. Second, the principle of political equality. The people(s) represented should have an equal share, directly or through their representatives, in holding that ultimate power of control. ${ }^{24}$ That means that no individual or people should be able to impose their views unilaterally or have significantly greater political power to determine the law than others. Among other implications, international political power should be proportional to the population of each people.

Third, the principle of deliberative contestability. The people(s) - or their representatives should be able to contest, through deliberation, the laws and decisions made internationally. They should also have the capacity to engage in deliberative interaction with each other, thus promoting public formal and informal debate. ${ }^{25}$ Fourth, the principle of human rights protection. Individuals' human rights that are constitutive of their basic moral equality and enable them to exercise ultimate control should also be protected in international law-making processes and institutions for those to be democratically legitimate. ${ }^{26}$

Any system of law-making may be considered democratically legitimate as long as it meets - at a minimal level - those four (scalar) requirements. The same may be said of the international law-making system and of the multiple public and private institutions involved therein. If creating a world parliament and calling for a global election is not an available option, at least for a while, we should explore other ways by which people(s) can exert ultimate control over those institutions. This turns the question of the legitimate institutions of international law-making into one of democratic legitimate representation.

In the first article we published about the democratic legitimacy of international law-making, ${ }^{27}$ we replied to this question with a two-pronged argument.

On the one hand, we defended an insufficiency argument according to which, due to their respective democratic deficits, neither public nor private institutions should be considered as sufficient, on their own, to represent individuals and people(s) of the world in a way that may be considered as democratically legitimate. On the contrary, we argued, the two types of institutions and representatives are best regarded as complementary and are both required to make international law democratically legitimate. On the other hand, we also developed a sys-

See Philip Pettit, On the People's Terms (Cambridge University Press 2012).

24 See Thomas Christiano, 'Democracy' in Edward N. Zalta (ed.), The Stanford Encyclopaedia of Philosophy $(2018)<$ https://plato.stanford.edu/archives/spr2015/entries/democracy/> accessed 31 March 2020.

25 See John Parkinson and Jane Mansbridge (eds), Deliberative Systems: Deliberative Democracy at the Large Scale (Cambridge University Press 2012); Samantha Besson and José Luis Martí, Deliberative Democracy and its Discontents (Ashgate 2006).

${ }_{26}$ See Samantha Besson, 'The Human Right to Democracy in International Law - Coming to Moral Terms with an Equivocal Legal Practice' in Andreas von Arnauld, Kerstin von der Decken and Mart Susi (eds), The Cambridge Handbook of New Human Rights: Recognition, Novelty, Rhetoric (Cambridge University Press 2020) 481.

27 Besson and Martí, 'Legitimate Actors' (n 12). 
temic argument claiming that those public and private representatives should be approached, first, as multiple in themselves with many public, but also private institutions representing the same people(s) and, second, as constituting, together, the complementary parts of the Multiple International Representation System (MIRS). We understand the Multiple Representation Model underpinning the MIRS as an aspirational model that should guide our normative approach to the international institutional order. According to it, the international order as a whole, qua system, should aspire to be democratically representative of all individuals and people(s) of the world and thereby grant full democratic legitimacy to international law-making.

More specifically, we developed the Multiple Representation Model as an alternative to the two most prominent models of international democratic representation. The first one is the traditional Statist Model. It relies on a monist view according to which there is only one kind of legitimate representative in international law-making: states and (state-based or state-like) IOs. As to the second model, the Dualist Model, it includes, besides public representatives like states and IOs, private institutions from the so-called 'global civil society', such as NGOs, TNCs, trade unions, churches and so on, in the group of legitimate representatives.

Our proposed model of international democratic representation shares one important tenet with the Statist Model: the idea that public representatives and, more specifically, democratically elected ones should retain a central role in international law-making. However, it also endorses a more expansive, and certainly non-monist, view that broadens the Statist Model in two different ways. First of all, the Multiple Representation Model grants other kinds of public institutions than states - such as regions and, importantly for this chapter, cities - a greater role than the one they currently enjoy, and even partial sovereignty. Second, it broadens the principle of state consent into something more general, and less focused on veto, that might be called the principle of state participation.

Importantly, however, the Multiple Representation Model also follows closely on the Dualist Model to the extent that even such an extensive revision of the monist view of international representation is insufficient, on its own, to secure democratic legitimacy. Public representation by states and IOs suffers from many democratic shortcomings that may only be compensated by including private institutions as representatives into international law-making processes. Still, our model differs from the Dualist Model in two respects. First of all, public representation remains at the centre of the MIRS, not least because of some of the important deficits of private institutions in terms of democratic representation. Second, private institutions may only participate as representatives in certain adequate contexts and fora, in certain specific ways and only to the extent that is necessary to complement public representation and overcome public institutions' democratic deficits.

In short, the Multiple Representation Model reacts to the underrepresentation of people(s) that characterizes the current international system where states and IOs still have the monopoly of representation, albeit in a way that addresses the democratic strengths and weaknesses of the various public and private institutions that come into account. It proposes to maximize the representation of people(s) by allowing a variety of public and private institutions to play different complementary representation roles in international law-making processes.

This is precisely where the 'multiplicity' of the model lies. We see a variety of public and private institutions of different kinds playing a legitimate part in representing the same individuals and people(s) in the international law-making process. That multiplicity does not, however, equate with mere plurality and hence align with radical pluralist models of the 
international order. True, there should be different kinds of representatives endorsing different specific roles and forms of participation in different contexts and fora, and some of them may even enjoy partial sovereignty. However, all of them should, ideally at least, complement one another and be harmonized into a unique representative system. In this sense, the MIRS comes close to the idea of 'systemic' representation. According to that idea, different representatives and different types of representation all have a role to play in an overarching system as long as their sum and interaction produce a fair and adequate amount of global or systemic representativeness. ${ }^{28}$

\section{LEGITIMIZING CITIES AS DEMOCRATIC INTERNATIONAL REPRESENTATIVES}

In our earlier piece on the subject, we approached cities only in passing, but considered them as an important part of a chain or continuum of public representatives, some international or supranational and others infranational. In order to grasp the exact role they should play therein, one needs to assess how cities fare with respect to the four principles of democratic legitimacy.

Based on those democratic principles, cities' increasing participation in international law-making processes may be regarded as particularly legitimate by comparison to that of other public and private representatives. There are at least two reasons for this. The first one pertains to the strong electoral, responsive representative features cities share with the main public representatives of people(s) (states), especially when compared to non-elected public and private institutions involved in international law-making (III.A). The second reason lies in their democratic strengths by comparison to the other elected public representatives currently involved in international law-making (states), and in particular their ability to compensate for some of the latter's democratic deficits (III.B).

\section{A Cities' Democratic Strengths Compared to Non-elected Public and Private Representatives}

In contrast to private institutions, but like other elected public institutions such as states or, in some cases, some of their (subnational) regional institutions, cities benefit from the greater political legitimacy that derives from the fact that their governments, at least in most cities belonging to democratic states, represent their citizens in an electoral, responsive way.

In democratic regimes, indeed, mayors and, more generally, city governments are periodically elected, directly or indirectly, by their citizens after campaigning on a certain agenda. Provided their proposed electoral agenda includes an external relations dimension, those mayors' popular election may also invest them with the mandate to defend a certain international programme. Subsequently, based on potential candidates' retrospective record on that international agenda, citizens may decide not to re-elect their mayor or city government at the

28 See Jane Mansbridge and others, 'A Systematic Approach to Deliberative Democracy' in Parkinson and Mansbridge (n 25) 1; Felipe Rey, 'The Representative System' (2020) Critical Review of International Social and Political Philosophy <https://doi.org/10.1080/13698230.2020.1808761> accessed 3 September 2020. 
next elections. The traditional picture then is that, through free and periodic elections, citizens delegate their powers to their local representatives, including on international matters.

This grants cities a special electoral, responsive kind of representativeness that allows them to rank quite well with respect to the four principles of democratic legitimacy. ${ }^{29}$ First of all, periodic elections ensure that city governments are responsive for what they do, providing those cities' citizens with effective means of ultimate control that usually also comply with the requirement of political equality - at least among enfranchised citizens. Furthermore, and again in democratic regimes at least, city authorities are required to operate within a (national and/or international) rule of law framework that fosters public transparency, accountability and scrutiny, thereby leading to deliberative contestability by the public. Finally, like other national authorities, city authorities have to comply with the requirements of international and, respectively, national human rights law, and they usually do.

This kind of electoral, responsive representative quality is available neither to private institutions (such as NGOs or TNCs) nor to non-elected public ones (such as most IOs, with the exception of the European Union) involved in international law-making. Of course, there are other ways in which those non-elected institutions may also claim to be representative. One may think, for instance, of NGOs as representing the interests of some people(s) internationally. As a matter of fact, 'claim'-based representation theories might account for such representativeness. ${ }^{30}$ The problem with those unelected public and private institutions is not so much whether they can effectively represent the interests of certain people(s) they 'claim' to represent. They certainly can, and often do. The relevant question regarding their legitimacy is whether they actually lie under the ultimate, effective control of the people(s) they claim to represent and hence do not dominate them. If they cannot be controlled by those people(s), indeed, they are merely imposing their will on them and do not have the democratic legitimacy to speak in their name in international law-making processes. ${ }^{31}$

In short, while free and periodic elections are not the only mechanism to exercise ultimate, effective control over one's representatives, they constitute a particularly good one. Accordingly, the main democratic strength of cities compared to non-elected private and public institutions is their capacity to be responsive to their citizens' interests.

\section{B Cities' Democratic Strengths Compared to States as Elected Public Representatives}

Cities may also be considered as having significant relative democratic qualities as representatives of people(s) by comparison to the main elected public institutions involved in international law-making: states.

Indeed, size permitting, cities exercise a local form of government and may, as a result, be regarded as having a special, more intimate connection with their citizens. Their proximity to those citizens explains, in turn, why they are usually more amenable to being controlled by them, more open to equal representation and to deliberative contestation than states. Based

29 See Besson and Martí, 'Legitimate Actors' (n 12).

30 See Michael Saward, The Representative Claim (Oxford University Press 2010); Jonathan Kuyper, 'Systemic Representation: Democracy, Deliberation, and Non-electoral Representatives' (2016) 110 American Political Science Review 308.

31 See Besson and Martí, 'Legitimate Actors' (n 12). 
on that special connection with their citizens, certain scholars consider cities as the natural space of political life. As Barber nicely puts it, '[T]he city ... has in today's globalizing world once again become democracy's best hope. ... If we are to be rescued, the city rather than the nation-state must be the agent of change. ${ }^{32}$

As a matter of fact, this comparative democratic strength of cities enables them to compensate for some of the democratic deficits that currently affect states in international law-making. In our earlier piece, we identified at least nine sources of concern with the democratic credentials of states. ${ }^{33}$ Of course, cities may share some of those democratic deficits. The fact is, however, that, with respect to some of them at least, cities may be better positioned than states to represent their peoples' interests.

First, with respect to the democratic requirement of ultimate, effective popular control, there are at least two main sources of democratic deficit for states: the existence of non-democratic states and the limited accountability of state governments, even in democratic regimes, when it comes to external relations.

This dual deficit may be partly addressed by including cities alongside states in international law-making processes. On the one hand, indeed, the fact that a state's regime is non-democratic does not exclude that its citizens can exercise more effective control (for example, through elections) over local governments, and especially city governments, than over national ones. This is, for instance, the case in China, where Chinese citizens have very little capacity of control over their national government, but can exert a greater degree of control, albeit limited and highly imperfect, over the mayors of some of their cities. ${ }^{34}$ On the other hand, it is likely that, once a city's citizens realize about the international law issues at stake in their local government's transnational activities, they will be able to gain control over them more quickly than they would over their national or even regional government. As a matter of fact, local elections tend to make those issues more visible than national ones. They are also better at fending off any undue exercise of power over the city's agenda, and especially at drawing public attention to lobbying campaigns led by TNCs or other private actors. One paradigmatic example of this was the city of Paris' pushing much more actively than the French government to achieve its own environmental agenda and to conclude an international agreement during the COP2 1 in 2015.

Second, with respect to the democratic requirement of political equality, states also suffer from several representation deficits, such as disproportions in demography, imbalances of informal power among them or the existence of permanent minorities.

Again, the inclusion of cities as representatives in international law-making may help address some of these deficits. Cities may certainly contribute to giving more voice to citizens of smaller (in population size), poorer, weaker or marginalized states. As we know, there is a high concentration of people living in cities today. Moreover, and contrary to what one may suppose, most of the largest cities are located in states that do not rank among the most powerful in the world. Thus, an international system that also includes cities as international representatives besides states will presumably respect the political equality among people(s) better than a system in which only states participate as representatives of those people(s). If Brazil,

\footnotetext{
Barber (n 15) 3-4.

See Besson and Martí, 'Legitimate Actors' (n 12).

34 See Baogang He, Rural Democracy in China. The Role of Village Elections (Palgrave Macmillan 2007).
} 
for instance, is in a weak position in some of its international negotiations at an international climate change summit, the fact that the Mayors of Sao Paolo, Rio de Janeiro and Brasilia also have a say may reinforce the power of the Brazilian government in those negotiations. In turn, this will help represent the interests not only of the people of those cities, but of Brazilian people more generally in international law-making.

Third, with respect to the democratic requirement of deliberative contestability, states suffer from important deficits, especially regarding a certain bias in the international representation of their own national interests at the price of common concerns and their use of consent as a veto right.

Those shortcomings may be partly addressed by the inclusion of cities alongside states in international law-making processes. First, cities' participation, especially when defending positions that go against their state's veto therein, may bring the latter to justify its positions when they differ and hence enhance international deliberation overall. This is also true of the role of cities in international standard-setting processes that take place outside of ordinary inter-state processes, and especially of their pursuit of inter-city initiatives or even city-IO agreements. The latter may indeed have an irritating role in regular inter-state law-making processes and could in turn generate more deliberation within them. Second, cities have clearly been associated with the promotion of global common concerns and have thereby contributed, when applicable, to enriching certain states' self-interested international agenda. This has been the case with the involvement of cities in international processes pertaining to climate change, migration and public health. This interceding ability of cities is actually something that many IOs in charge of those matters, like the UN, have understood. As a result, they increasingly require their Member States to reform their internal organization in order to grant more political powers to regional institutions, including cities, with respect to both internal and external affairs. In turn, this has led those states to give cities more participation rights in international law-making processes (for example, treaty approbation powers internally or, in rarer cases, even treaty-making capacities internationally).

Finally, with respect to the fourth principle of democratic legitimacy, the protection of human rights, it is well known that states have an ambivalent record in this area. Here again, some cities have demonstrated greater concern for human rights protection. That concern has actually often been the driving force behind their international involvement, for instance in the field of migrants' and women's rights or the fight against extreme poverty. In turn, this may enable those cities to raise the level of human rights protection within their respective states. ${ }^{35}$

In conclusion, cities may be regarded as contributing specifically to the democratic legitimacy of international law as representatives of their people(s), including by comparison to states and in complement to them.

\section{CITIES' COMPARATIVE DEMOCRATIC WEAKNESSES AS PUBLIC REPRESENTATIVES}

Despite their significant relative democratic qualities, cities are far from being perfect representatives. Not only do they also suffer from some of the democratic shortcomings of states,

35 See Chapter 18 by Martha F. Davis in this volume. 
but they also have some of their own. For reasons of scope, we will focus on the first two principles of democratic legitimacy only.

First of all, with respect to the principle of ultimate, effective popular control, one should emphasize that certain cities are not democratic. Their authorities cannot therefore be controlled by their citizens at all. This actually creates a dilemma that echoes what we already know of international representation by states: ${ }^{36}$ either the proposed participation of representative cities only benefits democratic cities at the expense of the protection of the political equality of the people(s) of non-democratic cities or, if it is generalized to all cities independently of their regime, it enables the agenda of non-democratic cities to dominate that of democratic ones at the expense of popular control and political equality again, but, this time, of the people(s) of democratic cities.

Cities may also suffer from deficits of their own in terms of popular control. Thus, and although this varies across states, one may claim that, given the limited competences or powers cities hold in external matters, popular control over their city authorities' international agenda might actually be harder to secure. One may also point out that cities have already delegated more substantial regulatory powers to administrative agencies than states, or that they have succumbed to outsourcing public services to the private sector to an even greater degree than states. The latter difficulty may actually even be enhanced by cities' direct involvement with TNCs. One may also cite to that effect the MoUs or the various international aid treaties concluded by cities with IOs, such as the World Bank or UN-Habitat, which all require cities to reform their internal political organization. Slowly but surely, those reforms have aimed at shaping so-called 'urban governance' (SDG 11) away from the 'government' by those cities' people and hence from those people's control.

Second, regarding the principle of political equality, cities may also suffer from a lack of political equality derived from imbalances of informal power among them. The same applies to the problem of disproportions in demography, since certain cities represent much larger populations than others.

However, there are further political inequalities that only apply to cities. Thus, unlike states, cities are not recognized as equal sovereigns (among themselves or with states) by international law and do not benefit, on that basis, from equal participation rights in international law-making. As a result, some cities take part in international law-making, while others do not. Even among those that do, and in the absence of an international law of 'cityhood' (in contrast to the international law of statehood), their constitutive elements and participation rights are not equal under international law. Moreover, cities cannot represent the whole world population since they are not the only inhabited territories. Even if cities around the world were granted equal participation rights in international law-making, the people(s) inhabiting rural areas could not be regarded as equally represented. Indeed, their fellow national citizens living in cities would also be - and additionally so, unlike in a federal state where all citizens are represented at all territorial and hence political levels - internationally represented by their respective cities. Finally, and in turn, those various forms of political inequality in city representation may actually even enhance the political inequality among states in international law-making depending on how urbanized the latter are.

36 See Besson and Martí, 'Legitimate Actors' (n 12). 
In short, cities are far from being perfectly legitimate international representatives. Despite all their democratic qualities outlined in the previous section, they should not therefore operate alone in the representation of the world's people(s).

\section{CONCLUSION: CITIES AS PART OF THE MULTIPLE INTERNATIONAL REPRESENTATIVE SYSTEM}

There are several reasons, we argued in this chapter, why certain cities' increasing participation in international law-making should be considered, under certain conditions, a positive development from the perspective of the democratic legitimacy of international law.

First, states are, on various grounds, unable to take sufficient action to address many pressing global challenges and, more generally, are not representing all their citizens effectively in international law-making. Second, cities are particularly well suited in many respects to address those challenges - due, for example, to their proximity to their citizens or their ability to coordinate transnational action - and are, for those and other reasons pertaining to the four democratic principles we presented, especially able to act as legitimate representatives of their citizens in international law-making. This is the case by comparison both to other public institutions (for example, states, IOs) and to private institutions (for example, TNCs, NGOs), whether those institutions are elected or not.

Importantly, cities may not claim to exert exclusive international democratic representation - no single type of public institution, and not even the state, may do so alone nowadays - to the extent that they also suffer from many democratic deficits of their own. While their specific contribution to international democratic representation should be emphasized, it is best constructed in combination with that of other public and private institutions representing the same people(s) in the framework of a multiple international representation system. According to the Multiple Representation Model, the international system as a whole should be considered as representative in a way that transcends the representativeness of each of its parts. It is only in this way that it can hope to overcome the respective democratic shortcomings and the over- or under-representativeness of every single public and private institution claiming to represent people(s) of the world therein. Approaching cities as a part of a continuum of international representatives implies insisting on their complementarity to the other representative institutions and on the completeness of the representation chain.

Of course, our argument in this chapter leaves many questions open. The most important one is how to organize cities' complementarity to the other public and private institutions involved in international law-making processes in order to fix their respective democratic deficits. The answer to that question is a matter of institutional design. Importantly, the MIRS attributes different kinds of institutions different roles and powers in different contexts. It depends on context and there can be no 'one (institutional) design fits all'.

Clearly, while cities qua elected public representatives should have priority over private or non-elected public representatives, there should be no hierarchy among elected public representatives due to their corresponding divided sovereignty. Indeed, the MIRS relies on a complex conception of sovereignty that is amenable to division into partial, overlapping and non-mutually exclusive sovereignties. Importantly, however, the rise of the representative role of cities in international law-making should not be identified with a weakening of the state's. 
On the contrary, on our view, cities' sovereignty and representativeness reinforce states' own sovereignty and representativeness, and vice-versa.

A deeper and more comprehensive explanation of how cities should be inserted in the MIRS alongside states and other private and public institutions will be a matter for another, longer paper. Here are some of the international institutional interactions with cities one could consider as directions for future research.

First of all, the universal scope of many IOs enables them to represent, albeit mostly outside of any form of electoral control, those who are left without additional representation by cities. IOs and cities can also complement one another effectively in their representation of the same people(s). To that extent, one should commend certain IOs for requiring their Member States to share some of their external powers with cities, or even associating cities directly into their deliberations and standard-setting procedures (albeit without circumventing states therein). In the future, certain IOs could even consider including cities among their members just as they used to also include other kinds of instituted territorialized political communities than states. ${ }^{37}$ Second, cities' representation of people(s) may also be complemented to the latter's benefit through representation by non-elected private representatives. It is clearly the case of NGOs, but one should not exclude for-profit civil society organizations such as TNCs. Under certain conditions, and it cannot be complete either, NGOs may give voice to the people(s) insufficiently or unequally represented by cities and empower those who have become persistent minorities in international law-making, such as rural populations.

In sum, IOs, states, subnational regional institutions, cities and civil society institutions should all work together in a more complex, but also more sophisticated system of international representation. The time has come, we believe, to experiment and construct those institutional interactions and continuities in order to enhance the overall democratic legitimacy of international law.

\section{FURTHER READING}

Samantha Besson and José Luis Martí, 'Legitimate Actors of International Law-Making: Towards a Theory of International Democratic Representation' (2018) 9(3) Jurisprudence 504.

Thomas Christiano, 'The Legitimacy of International Institutions' in Andrei Marmor (ed.), The Routledge Companion to Philosophy of Law (Routledge 2012) 380.

Jane Mansbridge and others, 'A Systematic Approach to Deliberative Democracy' in John Parkinson and Jane Mansbridge (eds), Deliberative Systems: Deliberative Democracy at the Large Scale (Cambridge University Press 2012) 1.

Michael Riegner, 'International Institutions and the City: Towards a Comparative Law of Local Governance' in Helmut Philipp Aust and Anél du Plessis (eds), The Globalisation of Urban Governance (Routledge 2019) 38.

37 See Jean-Marc Sorel, 'La prise en compte des collectivités territoriales non-étatiques par les organisations internationales à vocation universelle' in Société française pour le droit international (ed.), Les collectivités territoriales non-étatiques dans le système juridique international (Pedone 2002) 125. 